${ }^{I}$ Postdoctoral researcher at Federal University of

Rio de Janeiro (UFRJ), Graduate Program in Sociology

and Anthropology, Rio de Janeiro, RJ, Brasil

tiagocoutinho8o@yahoo.com.br

Tiago Coutinho'

\title{
FOREST SHAMANISM IN THE CITY: THE KAXINAWÁ EXAMPLE'
}

It was after three in the afternoon when Fabiano Kaxinawá and his brother Leopardo suggested that the rite's participants take a walk through the forest located close to the property where the meeting would be held later. One of the non-indigenous organizers told the group that the locale is very sacred having once been the habitat of extremely wise monkeys: Guapimirim is situated near to a forest reserve in the state of Rio de Janeiro where archaeologists found fossils of primates that inhabited the region millions of years ago. He added that it would be a unique opportunity to witness an ancestral ritual of discovering the forest preserved by the Kaxinawá people in a place energetically linked to humanity's ancestral past. During the walk, small monkeys appeared in the canopy of one tree, jumping from branch to branch. Everyone stopped to look, especially those in the rear group. Some took photos with their mobile phone cameras while others observed the movement of the small primates attentively. They were beautiful and inspired in the visiting city dwellers the idea that the forest should be preserved, as one of the organizers had remarked at the start of the walk. The enchantment and fascination awoken by this moment drew gasps from participants and quickly became a sublime experience for some of them. A few seconds after the sighting of the primates was announced by a young woman wearing a diadem of flowers, the shaman uttered a phrase that went down like a bomb with the rite's participants and organizers: "Just think how delicious these monkeys would be on the barbecue!" The shaman's proposal left everyone shell-shocked. The expression on the face of each participant clearly showed the lack of understanding of what was happening. ${ }^{2}$

The above passage is taken from field notes made during my ethnographic research on an urban curing rite involving the consumption of aya- 
huasca. Conducted by two young Kaxinawá shamans ${ }^{3}$ and organized by a group of Jungian psychologists, these Nixi Pae rites were offered on a regular basis between 2007 and 20 I I to educated, middle-class people in large Brazilian cities like Rio de Janeiro and São Paulo. Approaching shamanism as a dialogical category and urban shamanism as an important contemporary development of this dialogue, the principal objective of this article will be to call attention to a communicative device that mediates the mutual comprehension of the parties involved in these dialogues: namely, communication through equivocations.

Setting out from real world situations experienced at close hand over the course of a four-year period of field research into the Nixi Pae rites, the article looks to promote a discussion on the equivocal compatibilities that enable interactions between Amerindians and non-Amerindians in this context of urban ayahuasca consumption. The notion of equivocation explored in this text implies that sharing a certain language that employs synonyms from distinct cultural codes does not exclude the possibility of people believing that they are understanding each other, even though they are speaking about very different things (Viveiros de Castro, 2004). The ethnographic data collected during the period of fieldwork suggests that the urban rites of Nixi Pae explore the equivocal compatibilities between two terms that give rise to the communication in play: Yube and the unconscious.

\section{THE NIXI PAE RITES}

The Nixi Pae rites are Kaxinawa rituals where ayahuasca is consumed with the intention of acquiring knowledge and control over the different agents involved in events that encompass the question of health, preventing diseases and presenting itself as an instrument of negotiation in a world where many diseases are considered to result from the vengeance of the doubles of consumed animals (Lagrou, 2008). Nevertheless, this was the name chosen by two young shamans from the same ethnic group to denominate therapeutic encounters held in some of Brazil's major cities, like Rio de Janeiro and São Paulo, in which cures are obtained through the consumption of the Amazonian drink. ${ }^{4}$ While one of the shamans was responsible for the rites performed in São Paulo, the other, his brother, was responsible for conducting the rites in Rio de Janeiro. Sporadically the two brothers met at rites in São Paulo, Rio de Janeiro and some held in the city of Florianópolis. The rituals in these two major state capitals were held monthly, attended by an average of thirty people who would meet at ranches, farms and other locations close to urban centres to consume the Amazonian drink within the Huni Kuin tradition. Called the 'Nixi Pae ritual' by the organizers, the main objective of the encounters, as explained in the publicity materials, is the search for a 'cure': 
An ancestral curing ritual of the Huni Kuin people (also known as Kaxinawá) with the sacred ayahuasca drink (soul medicine) under the guidance of the shaman curer from the Kaxinawá Amazon, born in the Belo Monte village in the municipality of Rio Jordão, in Acre [state].

The Huni Kuin Knowledge and the Force of the Amazonian Forest: The Huni Kuin (Kaxinawá) people have a deep knowledge of the science of the forest and its mysteries. All knowledge is transmitted through Nixi Pae (Ayahuasca). In the ceremonies conducted by the shaman, the sacred drink indicates the paths to follow, teaches, cleanses and clarifies. It comprises a powerful cure at various levels (Publicity material, 2006).

The shamans belong to a family with an extensive tradition in shamanism and in positions of leadership. For this reason they were taught from childhood to defend the interests of their people in the big cities. The brothers are natives of the municipality of Rio Jordão, in Acre, close to the border with Peru. By their own account, they have consumed ayahuasca since the age of eight. The youngest was born in 1984 and left the village of Belo Monte aged thirteen to study at primary school in Rio Branco. The paternal grandfather of the two shamans is Sueiro Cequeira Sales Kaxinawá. Sueiro and his own brother Getúlio were responsible for the first demarcation of lands in the Rio Jordão region, supported by the anthropologist and then FUNAI employee Terri Aquino, expelling the rubber extraction bosses and creating Acre's first indigenous cooperative (Iglesias, 2008). The maternal grandfather of the two shamans was recognized a specialist in plants and an important shaman, Sheimutu. The shamans' mother is a leading artisan and specialist in the Huni Kuin graphic designs, while their father is Siã Kaxinawá, today the most powerful and wellknown figure of their people. Born in 1964, Siã was a student from the first indigenous teacher training class of the Acre Pro-Indian Commission (Comissão Pró-Índio no Acre: CPI-AC) and went to live in Rio Branco while still young where he became an influential political representative in the creation of the Acre Union of Indigenous Nations (União das Nações Indígenas do Acre), working in a political alliance with Chico Mendes in the I980s. Since I988 he has been president of the Kaxinawá Rubber Tappers Association (Associação de Seringueiros Kaxinawá: Askarj).

Compared with indigenous peoples from other ethnic groups, or even other Kaxinawá, the Huni Kuin brothers achieved something in approximately five years that no other shaman had achieved, providing indigenous therapeutic curing rites for non-Amerindians. The young men left their village in Acre and were soon welcomed at New Age spirituality centres that included the urban ritual of Nixi Pae among their mosaic of traditional knowledge practices, alongside yoga, biodance, acupuncture, shiatsu, shamanic rites of North American peoples, diverse massage techniques and alternative therapies. Between 2006 and 2009 the Nixi Pae encounters took place in Rio de Janeiro and São Paulo simultaneously. These encounters stimulated the formation of a hetero- 
geneous group of residents from the cities who shared an interest in preserving the culture of the Kaxinawá people, calling themselves 'Huni Kuin guardians.' This group, which is responsible for organizing the encounters in these two cities, sponsored three trips by the shamans to Europe to perform the ayahuasca consumption rites. As well as the rites, the shamans offer talks, workshops and dance presentations.

The main organizer of the Nixi Pae rituals in Rio de Janeiro is the white wife of one of the shamans, Fabiano. She is a psychologist whose postgraduate research concluded with the presentation of a Jungian-inspired monography on the visions provoked by consuming ayahuasca. Since then she has presented herself professionally as a transpersonal psychologist working along Jungian lines. She runs a variety of courses in emotional relearning through art therapy, as well as travelling the Red Road 5 of shamanism since 2000 . The psychologist says that she is initiated into the Huni Kuin and Ojibwa shamanic traditions.

In this context of urban consumption of ayahuasca, the equivocal compatibilities that enable interactions between Amerindians and non-Amerindians were observable as soon as the couple got together, when the main terms of the dialogue were put into practice during the ritual: Yube and the unconscious. Ayahuasca consumption places on an equal footing, within a dialogical context, aspects from an Amazonian cosmology contributed by the Kaxinawá shamans, and traces of the worldview developed by Jung contributed by the shaman's wife. By presenting a number of interactive contexts that include and extend beyond the spatiotemporal axis of the rite itself, I seek to explore the equivocal sensation of mutual comprehension that unfolds as a result of the 'synonymy effect,' which, for example, places spirits and mythological beings on the same level as psychological and emotional states, creating a metaphorical continuum between those involved in the communication. We should explore a little more closely how this communication unfolds during the ritual moment.

\section{YUBE AND UNCONSCIOUS IN THE RITUAL PROCEDURES}

Over the four years of research (2007-20II) I participated in eighteen rites, twelve in the city of Rio de Janeiro, three in São Paulo ${ }^{6}$ and three in Florianópolis. After taking part as a spectator in two encounters, I introduced myself to the group as a researcher from the area of social sciences who was interested in producing a doctoral thesis on the rites and their repercussions in the contemporary world. Welcomed by the shaman and by the organizers as one of the 'Huni Kuin guardians,' I was authorized to participate in different stages of these rites and in events connected to them, observing small particularities of this dialogue realized through equivocations enabled by the ayahuasca en- 
counters. The Nixi Pae rites that I was able to accompany during my research almost always followed the same procedures.

Ideally the ceremony was held in locations at some distance from the city and containing natural attractions like forests and rivers. The participants are greeted by the shaman's wife and by the owner of the venue where the ceremony will be held. For three or four hours the participants of the rites have time to get to know each other, exchange experiences and observe Kaxinawá objects - baskets, necklaces and other craft objects - typically sold at improvised stalls. Called by some the 'curing circle,' 'shamanic circle' or 'circle of truth,' the place where the rite takes place should be surrounded by greenery, rocks and grass, and allow a circle to be formed around a bonfire. Most times, the rites are preceded by another ceremony known as the 'sweat lodge' or the 'temazcal ceremony,' conducted by a therapist trained in American shamanism, including initiation into the Lakota tradition. ${ }^{7}$

The Nixi Pae rite begins with the shaman's wife asking to speak. In her introduction she says that everyone is gathered there to discover a little about the path of light walked by the peoples of the forest for millennia. This moment will afford the people of the cities the unforgettable experience of learning about and experiencing the path. According to the psychologist, this is a knowledge that, despite all the attempts by white people to contaminate the path through their politics, economics and religion, it has remained intact for millennia, dormant in our unconscious. She reminds the participants that the path of ayahuasca is the path of light and love, the opposite path to the city. According to the organizer, this is why vomiting or unpleasant feelings may become manifest during the journey, since a purification towards the truth is undertaken over the course of the ceremony. She continues her talk by telling those present that other religious groups and currents use the Amazonian drink as a spiritual tool for the same purpose of attaining self-knowledge. However, the urban Nixi Pae rites diverge from these other approaches since they are pure rites based on ancestral knowledge rather than the outcome of a mixture of religious practices. She explains to those present that the journey made through ayahuasca will be conducted by the white Yube, a mythic being that embodies the essence of all things, which for the Kaxinawa assumes the form of a snake. She also recalls that this representation is present in Kaxinawá culture, in their paintings, designs, motifs, and even in the panoramic view that they have from the air when they fly over the rivers in Kaxinawá lands.

After this explanatory introduction, it is the shaman's turn to speak. He begins by thanking everyone for coming, remarking that the moment is very special for his people: from a young age the Kaxinawá go into seclusion in the forest in order to learn about plants. Drawing an analogy with "white people's schools," the shaman tells everyone that this is the moment for him to become the teacher. He tells the participants that he already had the chance to go to 
indigenous school and white people's school, and that, backed by this experience, he could assure those present that the two were undoubtedly the same thing: a place for transmitting knowledge. Hence, the encounter of people gathered to consume ayahuasca is a moment of learning and great respect for the things held sacred by his people. Fabiano asks the participants not to make jokes, laugh or disrespect the music since everything about to be transmitted contains what is most important for their people, hence the need for it to be preserved.

As well as Nixi Pae, another two substances may form part of the curing process offered in these rites: rapé and kampô. The shaman says that, for the Huni Kuin, rapé (snuff) is a powerful medicine that connects the individual with the energy of Youshibu, the one who created all the things of the world. For this reason, the rite's guide warns that the substance must be used with huge respect, since it is extremely sacred for his people. Thus rapé should never be mixed with alcohol, nor be taken just anywhere. According to information from the shaman, the rapé used by him is made from a combination of native Amazonian plants, including various kinds of tobacco.

In relation to the other substance, kampô, the shaman warns that it should not be mixed with Nixi Pae, but used only when the "effect of the ayahuasca has faded." In some urban Nixi Pae rites, the young shaman told a summarized version of the Kaxinawa myth on the emergence of kampô:

One of our people's myths tells that one time the Indians from the village had become very sick. The Shaman Kampô had already done everything he could to cure them. All the medicinal herbs that he knew had been used, but none had been able to rid his people of their torment. So Kampô went into the forest and, under the effects of Ayahuasca, was visited by the great God. The latter carried in his hands a frog, from which he extracted a white secretion and taught us how to apply it to the sick. People say that whoever takes the vaccine and ventures into the forest to hunt will be lucky as the person emits a green light, the colour of kampô, and this attracts the game animals. So when the game approaches, the Indian can catch the animals and take them back to the village. (Fabiano Kaxinawá).

After presenting the rite's guides and all the participants, the shaman stands up and, a small glass bottle in hand, scatters eucalyptus essence and mint essence around the fire, asking the organizers to light incense to fill the space with the appropriate aroma for receiving the boa constrictor (jiboia) songs. While the shaman returns to his place in the centre of the circle, the guide tells everyone to close their eyes so they can enter a state of calm and tranquillity. He then begins to sing in the Hatxã Kuin language, accompanied by his wife and the other organizers. The song asks for permission from the white boa Yube to enter its world. The song's words are read from a book placed in front of the couple, while the organizers have a sheet of paper to help them. After the song has concluded, there are a few minutes of silence and reflection. Next, the rite's guide stands up and moves in front of the fire to serve the first 
dose of ayahuasca from a cup held with both hands, reflecting the red light cast by the fire. Whispering some incomprehensible words, the shaman raises the cup to his mouth and blows on it a few times, uttering the following words: 8

We are gathered here to ask permission to enter the world of the white boa, always respecting its paths and choices, asking permission from the Huni Kuin people for the 'people of the big city' to learn a little of this wisdom, which is good wisdom. (Fabiano Kaxinawá).

The shaman then begins to distribute the ayahuasca, raising the first cup to the fire before passing it from hand-to-hand around the circle. When the glass returns to its starting point, the shaman sings a quick song and then solemnly downs the contents himself. After drinking, the guide remains with his eyes closed for a few minutes, uttering words that are impossible to reproduce. The next person to drink is his wife, followed by the other organizers. The shaman sits in the middle of the circle and asks each participant to come over one-by-one to sit before him and receive the glass. As he hands over the cup, the young shaman asks each person individually whether it is the first time they have used the Amazonian drink. If the person has already participated in another rite with the drink, the dose is given in full. If not, the person receives a half dose. Whispering and blowing alternately in the participant's ear, the shaman asks the person to hold the glass while he fills it with Nixi Pae. After ingestion, the shaman offers a bowl with fruits to alleviate the bitter taste of the drink.

A long moment of silence descends on the circle while all the participants sit with their eyes closed. The silence is eventually broken by the shaman who, in a high pitch begins a song accompanied by a gourd rattle. In this first song, the shaman is unaccompanied by his helpers who remain busy tending the fire during the rite, paying constant attention to the reactions of the participants, especially those who are experimenting the Amazonian drink for the first time. Having completed the song, the shaman asks whether everyone is fine and informs them that this particular song is sung to "summon the force of the Huni when the Nixi Pae ritual begins" - in other words, a song that allows entry to the world of the boa. The first moans, vomiting and other reactions are observed among the participants. A sequence of songs then begins which are accompanied by the organizers vocally and with percussion instruments such as the gourd rattle or small drums, other kinds of rattles and, in some cases, clapping. The songs are always preceded by a quick explanation of their purpose and effectiveness. No kind of bodily expression is permitted during the rite: the shamans ask the participants to remain seated and concentrated.

Two or three hours after the distribution of the first glass, the rite's guide stands up and begins all the procedures necessary for the second dose to be served. Once again everyone goes to sit one-by-one in front of the shaman, who 
follows the same formalities observed with the inaugural dose. The second blessing is accompanied by the song that "summons the force of the vine," which should be sung with considerable concentration and determination. After this phase, the participants are already starting to exhibit the effects of consuming the substance: recurrent vomiting, people wrapping themselves with blankets and sheets as they start to experience chills, outbursts of weeping, muttering to themselves and small involuntary actions like trembling and yawning. At this moment the shaman chants a sequence of songs without pause, speaking fewer and fewer words in Portuguese. The third dose is served after a shorter interval than the previous one and the entire procedure repeated.

After the third ingestion of ayahuasca, the shaman may need to shift his attention to a few cases that are hindering the progress of activities. In many of the rites I attended, the shaman had to give special attention to those who had "passed the limit." When the crying fits lead to shouting and brusque bodily movements, and the vomiting becomes constant, the resulting noise ends up disrupting the concentration of others. In some cases that I witnessed, when possession by some spiritual entity occurred, the shaman would lead the participant to a spot in the forest, getting the person to kneel down while he chanted a song more appropriate to the moment at hand.

As the first rays of sunlight appear, the shaman asks all the rite's participants to stand up and hold hands. A song is then begun to which everyone should listen with their eyes closed, since "the snake is spitting everyone out of its belly." At the end of the song, with day breaking, the shaman hands over to his wife. The psychologist thanks the Huni Kuin people profusely, saying that the experience is priceless and that we owe much to this people for having kept this knowledge out of reach of the destruction brought by the whites. She hopes that the unique and deep experience leaves a definitive mark on the life of everyone present and that it helps towards the cure sought for each problem.

The ritual procedures described above refer to a 'standard rite,' that is, a summary of practices that varied little during the encounters in which I took part. Variations in ritual procedures mostly arose from the presence of guest participants from other religious or spiritual orientations that "respect the Indians." Although the Catholic religion is constantly accused of destroying Huni Kuin culture, other religions or spiritualties are welcomed in this ritual. During the fieldwork period I observed followers of Hare Krishna, Santo Daime, Barquinha, Buddhism, yoga and diverse other areas of New Age spirituality. At a particular point of the ritual, these people were invited to sing, play instruments, speak about spirituality and even lead collective prayers.

Based on questionnaires distributed by the organizers, I was able to develop an informal profile of the kind of people who seek out this therapeutic rite. They comprise men and women aged between twenty and seventy (the rituals are barred to people younger than eighteen) from the middle-upper class with a fairly high level of education. Participants often include people 
with doctorates and university professors. Most had already participated in some activity linked to the New Age universe and, in some cases, included professionals from the area: yoga instructors, homeopathic doctors, holistic therapists.

The information gathered through questionnaires and conversations with the participants suggested all kinds of motives for wishing to take part in the rites, making it impossible to isolate any specific motivation as a constant. Reasons can vary from the search for comfort after the death of a loved one to someone deciding to change their lifestyle and turn to the shaman for help in this transformation. The participants' testimonies do, however, include a recurrent search for 're-equilibrium.' According to participants, events happening over their lives had led to a loss of enthusiasm, vitality and even the will to live, depression, personal and financial problems, and inexplicable physical malaise - all facts interpreted by participants in the urban Nixi Pae rites as an imbalance in a life that was once normal.

One of the main therapeutic potentials of ayahuasca explored by the urban Nixi Pae rites is the vine's capacity to induce visions. This state generates important psychic material that needs to be interpreted by the person seeking the cure. During my period of fieldwork I collected approximately I50 testimonies, texts and drawings produced by participants of the urban Nixi Pae rites that depict the lived experience in the world of visions. According to the organizers, the participant can reach the world of visions at any moment of the rite after ingesting the first dose of ayahuasca. During the stage of writing and systemizing the research data, images and accounts referring to death were recurrently observed.

Innumerable testimonies were collected over the research period telling of terrifying experiences with ayahuasca. Though the individuals, places and personal life stories vary, the moments of despair, compulsive crying and vomiting are recurrent elements in the urban Nixi Pae rites. Accounts and designs of dragons, flames and demons are commonplace, along with traumatic memories, symbols of death or funeral imagery. Those participants who required special care mainly complained of the sensation that they were dying and required immediate help. The large majority of the testimonies collected in the rites reported a pleasant feeling of relief after experiencing images of death and undesired states. Participants considered these latter experiences to be a necessary stage of the curing process.

According to the organizers, the songs are the biggest contribution made by the Kaxinawá people in terms of helping people access realities very different from their everyday lives. The sounds and melodies establish pathways that prevent feelings of anguish, fear and disequilibrium from taking over participants as they enter the world of ayahuasca. In the urban Nixi Pae rites, the songs are performed in the Hatxã Kuin language after the first dose of the 
Amazonian drink are offered to the participants. The songs depict the different stages encountered by the individual as they become immersed in the world of the white Yube, with the shaman playing a decisive role in choosing the right song for the right moment. The names chosen for the songs relates directly to the ritual moment when they are applied: "a song for the brother who is feeling unwell and needs to be set back firmly on his feet," "a song for renewing the body," "a song to strengthen the mind," "a song to cleanse and calm," "a song to remove fear and restore equilibrium," "a song with the force of tobacco," "a song to remove the brother's bad thoughts" and "a song for emerging from the vision with strength." The songs are repeated over the course of the rite for more than six hours, interspersed with small intervals of silence.

After eight years promoting meetings in which people could consume the Amazonian drink in Rio de Janeiro, the young shaman had a vision during the night telling him that "he should teach the city people the correct way to sing." From 2009 onward, therefore, he began to offer city dwellers a course translating the songs performed in the Nixi Pae rites and teaching the 'correct' pronunciation of the Hãtxa Kuin language. Lasting an hour, the class would begin with a Kaxinawá song chosen by the shaman, accompanied by his gourd rattle, followed by asking Yube for permission to transmit the songs to the urban residents. Assisted by his wife, the shaman would hand out a sheet of paper with each song, asking the participants to accompany the song in whatever way they felt appropriate. Subsequently he would translate the text in detail, replying to people's doubts and providing the meaning for each word of the text, printed in full in the Kaxinawá language. Lengthy discussions emerged on translating the key concepts, the use of words and doubts concerning the language's grammatical rules.

At various moments of the course the shaman would tell the students the correct way to pronounce certain elements, like the 'e' in Yube, since, according to him: "to receive the energy and force of ayahuasca it is necessary to know how to sing the songs properly and know what one is singing." "My objective in this class is to transmit a little of my culture and to show the right way of following the path of the boa." The shaman also emphasized that the songs performed in the urban rites are sacred to his people and that it is his duty to protect and transmit them to the nawa in the city in a secure way. Hence, he insisted that people should not sing the songs at parties, while showering or in any other inappropriate situation, since he has sole and exclusive responsibility for transmitting this knowledge. During the song lessons, Yube appears in most of the translations as an omnipresent being who rules the things of the world. The shaman constantly translates Yube as jiboia (boa constrictor), however a boa that is of everyone and for everyone: "The thought of the boa is planted in all people [...]. The path of the boa is for everyone [...]. 
It is the supreme knowledge of the boa [...]. We were born with this force/With the force of the boa." At the end of the translation class in which this song was studied, a young woman asked the shaman whether the term Yube could be compared to the western notion of God. After a few seconds of reflection, he shook his head and told the young woman;

The God of you people here in the city is not for everyone, he only stays in the church, in the religion and in moments of festivals; the force of the forest is everywhere and within reach of anyone. Yube is not the owner of ayahuasca in the forest only, it guides the work here in the city too. That's why Yube came to bring cures and peace. That's why ayahuasca is not a drug that induces madness, it is a drink of knowledge. (Fabiano Kaxinawá).

Although the young shaman, assisted by his wife, makes considerable effort to teach the residents of the big metropolises the correct way to pronounce the songs and understand their content, most participants evidently try to accompany the melody without any notion of how the words translate into Portuguese. The reality of this ayahuasca consumption rite contrasts, for example, with the situation depicted by Rehen (20I I) where Dutch followers of Santo Daime saw the need to learn to speak Portuguese in order to fully understand the message transmitted by the hymns sung during the rites of the neoayahuascan religion in question. In this case, comprehending the hymn lyrics is clearly important to the overall quality of the religious experience.

\section{URBAN NIXI PAE: VISION OR POSSESSION? THE QUESTION OF THE POWER OF SORCERY}

By exploring an event identified by the main organizer as problematic in terms of the curing objectives of the urban Nixi Pae rites, we can observe how the question of sorcery creates a field opportune for communication through equivocations. Nonetheless, this does not result in the feeling of mutual comprehension. Communicative equivocation occurs insofar as two completely distinct views of sorcery are applied to the same sequence of events. In seeking balance through ancestral knowledge, the organizers of this therapeutic rite look to remove any hint of sorcery from the shaman. This is done because the notion of sorcery shared by the organizers is one commonly found in the collective Brazilian imagination, where shamanism is associated with malign spiritual work responsible for inciting negative feelings like envy, betrayal and hatred through spirit possession. Over the recent history of Brazil we can observe how sorcery was directly associated with African-based religions persecuted by the State since the era of colonization to the mid-twentieth century. ${ }^{9}$ On the other hand, one of the participants of the rite thought that spirit possession could provide a valuable input to the ritual efficacy of this ceremony. The equivocation was observed at the moment when one of the participants 
was possessed by a spirit during a Nixi Pae rite, thus making evident the two notions of sorcery in play, one negative, the other positive.

I transcribe part of the shaman's wife's talk during the opening of the weekly meeting:

I want to tell you all that what happened during the previous rite cannot happen again! This is an original ancestral ritual and it is our duty to modify it as little as possible. We cannot interfere in the culture of this people. We have already seen all the atrocities that the West committed, we must protect the Kaxinawá, that is our mission. That is what a guardian is, safeguarding a millennial culture from all of the West's mixtures, the only result of which is to modify and destroy a knowhow that has remained intact in the forest for millennia.

The psychologist reported that during the previous rite one person had become possessed by a black ancestral entity, a preto-velho, and had to be removed from the circle. She required special attention from the shaman, who had to sing for a long time to cure her, temporarily abandoning the other participants. The testimonies said that after the fourth dose of Nixi Pae, a young woman of about thirty returned to the circle, sat down and began to emit strange sounds while her eyes rolled compulsively. Immediately two organizers went to offer her a glass of water and try to establish a dialogue to alleviate the situation. Those present at the ritual recalled that the offered glass was immediately cast aside after the young woman had said, in a distorted voice, that she did not need water at that moment. They added that two participants who had been sat next to the young possessed woman immediately stood up afraid of the unexpected reactions, spilling the contents of the cups and flower vases placed in front of them. With the whites of her eyes showing and both her hands twisted backwards, the young woman coughed compulsively and drew closer and closer to the fire.

This unexpected turn of events led the two main organizers to remove the young woman from the circle, taking her to a spare room along with the shaman, who had immediately stood up to control the situation. According to witness accounts, the concentration of the other participants was disturbed. Their meditative state had been brusquely interrupted and all the participants forced to open their eyes. At this point the ritual was suspended, the lights turned on and only the shaman's wife remained in the circle as the Kaxinawá shaman and the other four guardians led the young woman to a small room intended for curing anyone who had become possessed. The shaman led her to a room approximately ten metres from the hall where the rite was being held. The young woman's feet and hands were held tight by the organizers while the shaman sang repeatedly the "song for removing the brother from negative energy."

One of the organizers said that the young woman had been uttering nonsensical phrases in a distorted voice, interspersed with yelling and weep- 
ing. He added that another young woman had been squirming about violently and more than once had tried to bite the arm of the organizer holding her. The psychologist said that the cries and groan made by the possessed inside the room were incompatible with the meditative state sought by the rite and asked the non-possessed to wait on the floor below for a few minutes until the situation calmed down. The shaman took around half an hour to normalize the ritual procedures. He said that his initial decision had been to immediately suspend the doses of drink that were due to follow, trying to emphasize as much as possible "the songs for cleansing the energy of the place."

The shaman admitted to the guardians that he was unprepared to deal with this kind of situation. In his view, possession involves another type of force, another type of curing work that he is not authorized to undertake. He said that he had been taught since childhood to know the spirits of the forest and animals, not the spirits of other people who wander about aimlessly. According to the shaman, the rites conducted by himself and his brothers are all about self-knowledge and individual cleansing, and have nothing to do with possession or sorcery. He added that while he has great respect for other traditions that devote themselves specifically to curing work, this is not his own speciality. He pointed out to everyone that the Kaxinawá repertoire does not include any song telling the correct way to deal with spirit possession.

Supporting the shaman, his wife stated that: "We guardians have real sympathy for the many other brothers who use ayahuasca to obtain cures. Temples and tendencies exist where possession forms part of the doctrine and cosmology. But not here in the Nixi Pae rites! Here it's an original, pure rite, while possession is the result of many mixtures that influence the white man." Concurring with the shaman's wife, one of the organizers evoked his experience in the villages on the Jordão River: "That's true, you're exactly right. The Kaxinawá are tranquil, the rites in the Huni Kuin villages are performed in the quiet of the night when the only sound perceptible is that of the forest, the sound of the insects and the nocturnal animals. The songs should be performed in silent and tranquil locations for them to attain the desired objective. Night-time and silence are perfect for visions and for accompanying the songs. In this setting the force of the boa accompanies and guides you without any problem," the guardian said.

Citing her personal experiences of ayahuasca consumption in villages on the Jordão River the shaman's wife argues that in the urban Nixi Pae rites, spirits and invisible energies are meant to be visualized and experienced in a meditative form, while other traditions need to incorporate knowledge through a loss of consciousness. The final decision of the meeting was to send those people with a predisposition towards possession to another ritual like the one performed in the Arca da Montanha Azul religion. During fieldwork, I took part in three Nixi Pae rituals where at least one participant became possessed by a 
spiritual entity after consuming ayahuasca. Unlike the case explored above, though, via the accounts of people present, the cases of possession that I witnessed were resolved discretely without calling the attention of the other participants.

The frontiers established by the rite organizers to ensure the cure of urban residents in search of equilibrium through ayahuasca effectively neutralize an important aspect of the Kaxinawá shamanism observed in ethnographic studies: the power to "cast sorcery spells" (Kensinger I997, Lagrou 2008). The perspective adopted seems to ignore the ambivalent and bellicose potential observed in these studies, the so-called "dark side of shamanism." According to Lagrou (2008), anthropologists, in line with their interlocutors, have tended to define the shaman (translated as pajé) as prototypically a curer with the capacity to make visible pathogenic objects sucked out of the body of a sorcery victim.

Looking to avoid any equivocation concerning this part of the communication, all the potentially malign power associated with casting spells and causing diseases is removed from the urban Nixi Pae rites. According to the patients who seek equilibrium, "the Indians only mess with good things, not bad things." From the viewpoint of those who seek out a cure by reobtaining equilibrium through the consumption of ayahuasca, feelings like 'revenge,' 'settling scores,' 'possession' and 'bad luck' must be rapidly neutralized or stabilized by the Kaxinawá shaman and his wife since they hinder the curing process. Through the problem with the possession by spiritual entities, we can perceive how the specific ritual character of this shamanism, eliminating its obscure and predatory aspect, is fundamental to the urban proposal of the Nixi Pae rites.

\section{COMMUNICATION THROUGH EQUIVOCATIONS}

The main hypothesis of this article is that the notion of the unconscious, regularly employed by the rite's guides in different communicative contexts, resonates in various aspects with the Kaxinawa experience of synthesis transmitted by Yube. Hence the mythic being Yube and the analytic category unconscious, though pertaining to distinct cultural universes, are the main points of resonance explored in the translation proposed by the young shaman and his wife for transmitting the notion of mutual understanding to those involved in this dialogue mediated by the consumption of ayahuasca. Within this communicative field, however, there still exist certain communicative contexts where points of resonance are absent, including, for example, the case of sorcery, or Norwegian funding, or the "ethnographic anecdote of the monkey" cited in the introduction to this text. In these cases the differences between the universes placed in dialogue in the rite become more accentuated, produce dissonances, 
with responsibility falling to the shaman to take the necessary measures for the synonyms to be mobilized at the right moment, restoring the feeling of mutual comprehension of the dialogue among participants.

Though involving two ethnographic realities completely distinct from the one presented here in this article, the texts by Losonczy \& Mesturini (20I I) and Viveiros de Castro (2004) propose an important definition of communication through equivocations. We can highlight some aspects of this communication in which the equivocation is not "[a]n equivocation is not an error, a mistake, or a deception. Instead, it is the very foundation of the relation that it implicates, and that is always a relation with an exteriority." (Viveiros de Castro, 2004: I I). While an error or mistake can only be determined within a single cultural code, the equivocation reveals the interval between different codifications that explore the points of apparent continuity. In communication through equivocations, what founds the relation of meanings between two distinct discourses are its shared referents, which produce parallel visions of the same object. The notion of equivocity invoked by the author implies that sharing a particular language that explores synonyms from distinct cultural codes does not exclude the possibility that people believe that they are understanding each other when they are actually speaking about very different things.

Comparing the data collected during fieldwork relating to the visions provoked by ayahuasca consumption, the ideas projected on the shaman prior to the rite and the effects of consuming the drink on the cure of pathologies with the Kaxinawá ethnographic material gathered by Lagrou (2008), we can assert that a shared experience guides ayahuasca consumption in the cities and forests alike: the lived experience of processes of dying, losing one's body or 'becoming other.' This shared feeling further accentuates the sensation of mutual comprehension among those involved in the urban Nixi Pae rites. According to Lagrou (2008), the first experience that the Kaxinawá have when taking ayahuasca is one of death. Just like the image transmitted by the shaman to urban participants at the moment of consumption, the anthropologist says that the body of the initiate is squeezed and subsequently swallowed by the anaconda. The initiate experiences darkness and fear, thinking all the time that he is going to die because the snakes are eating him, and shouts out in despair.

During my research innumerable testimonies were obtained telling of terrifying experiences with the ayahuasca drunk in the urban Nixi Pae rites. In some encounters, I witnessed up to five participants being led away from the circle for special treatment. The images of death and the negative experiences unleashed by ayahuasca are interpreted by participants as a decisive moment in the therapeutic process proposed by Fabiano and his wife. Projecting onto the shaman the image of a guide who will safely lead the person through the experience of reliving past traumas forgotten over time and through psychic 
defence mechanisms, the participants of the urban rites experience processes involving a lack of comprehension and nonsense, which, confronted with disequilibrium, produce cures or restore a lost sense of balance, just like the 'white beach' described by Lagrou's interlocutors (2008).

The image of the body of the ayahuasca consumer being swallowed by the snake resonates with what the shaman's wife identifies as an important therapeutic mechanism in the Nixi Pae rites: abreaction. Citing passages from her intellectual mentor Carl Jung, the psychologist tells the participants before the rites that attaining this state requires an emotional release through which the affect linked to a traumatic memory is freed, passing from the unconscious to consciousness. In her words, ayahuasca provokes a moment of catharsis in the consumer. ${ }^{\text {io }}$

Consequently, the movement made by Yube in swallowing the body of the drinker and taking him to its world before spitting him out may encounter strong points of resonance with the Jungian therapeutic process, specifically its search for an emotional release from a previously unconscious trauma that comes to consciousness with the consumption of ayahuasca. Even though for the Kaxinawa this experience has nothing to do with the past, the death experience produces a conceptual bridge between two worlds in which images of the snake and the unconscious encounter a metaphorical continuum between cultural frames that enact their metaphors in distinct ways (Losonczy \& Mesturini, 20II).

Observed from the viewpoint of the young shaman, Yube is the great mythic being with the ability to transport itself between the different worlds that make up the cosmology of this people. The role of Yube with its designs and visions is to communicate a synthetic perception of the simultaneity of the different realities experienced by the Huni Kuin. The men who drink the vine have access to a form of knowledge inaccessible to daytime consciousness. Its visions allow the exploration of worlds known and imagined through this ontology whose concepts and categories used to refer to the 'other' are conceived in such a way that they end up referencing the categories of identity and alterity alike, excluding any possibility of essentializing the terms involved. In the urban Nixi Pae rites, the Kaxinawá cosmology encounters a reflexive-theoretical viewpoint onto the world based on the maximum essentialization of the terms.

Comparing a chain of dialogical contexts involving such distinct cultural universes - one fluid with images waiting to be defined, the other with crystallized images in search of synonyms - we can suggest that the urban Nixi Pae rites mobilize a communicative model based on a controlled form of rearranging equivocations or misunderstandings according to the interests in play. The encounter of a young Kaxinawá man and a Jungian psychologist set off a process of communication and exchange that presumes a common un- 
derstanding based on a mutual equivocation or misunderstanding. An interactive communication process that produces, constructs and feeds discourses, practices and rites, which, through a series of equivocations, connect ritual consumption with the activation of the category of 'shamanism' as a mediator of dialogue. It is within this process that the young man has become a great shaman in the urban landscape.

Received on 09/I4/20I5 | Approved on 0I/I8/2016

Tiago Coutinho is a postdoctoral student on the Graduate Program in Anthropology and Sociology at the Federal University of Rio de Janeiro (PPGSA/UFRJ). A member of the Arts, Images and Ethnological Research Laboratory (NAIPE), he has published an interview with Anne-Marie Losonczy (2010), 'Drogas: perspectivas em Ciências Humanas' (2008), and the article 'Festivais de música eletrônica: os usos do corpo em uma festa contemporânea' (2008). 


\section{NOTES}

I I would like to express my special thanks to the anonymous reviewers whose comments and suggestions contributed decisively to the final version presented here.

2 Text based on annotations made in the first half of 2008 at a Nixi Pae ritual held in Rio de Janeiro.

3 Also known by the autodenomination Huni Kuin.

4 Nixi Pae is produced through the decoction of two native plants from the tropical forest, the vine Banisteriopsis caa pi (also called caapi, douradinho or mariri) and leaves from the Rubiaceae plant Psychotria viridis (known as chacrona) which contains the active principle dimethyltryptamine (DMT).

5 The Red Road is a non-profitmaking international institution that defends the religious traditions of the indigenous peoples of North America (USA and Canada). The institution promotes Pan-Indianism which places a huge diversity of peoples from this region under the same label. The group became known as the origin of the New Age movement in the rg7os.

6 It is worth observing that other organizers exist in São Paulo who, though communicating with their Rio de Janeiro peers, carry out different kinds of work.

7 A tent (Inipi) is set up in a tranquil spot in the middle of natural surroundings so that all the participants are in contact with the earth. Placed in the middle of the tent are white-hot rocks that have been heated in the fire for some time. These are subsequently doused in water mixed with aromatic and medicinal herbs, releasing steam which fills the entire environment. The stones are placed gradually, usually in four circles each with is stones. The temperature inside the tent can reach $50^{\circ} \mathrm{C}$.

8 The words are spoken in Portuguese mixed with the Hatxã Kuin language. During the period of fieldwork the term haux was frequently used by the shaman as a salutation employed at the end of the phrases. After someone has spoken, whether the shaman, his wife or anyone else during the rites, talks and workshops, all the participants are induced to repeat the word three times: "Haux, haux, haux." 
9 Candomblé arrived in Brazil between the sixteenth and nineteenth centuries with the trade in black slaves from West Africa. It was heavily repressed by the Portuguese colonizers, who considered it sorcery. To survive the persecutions, the followers began to associate the Orishas with Catholic saints in a religious syncretism Iemanjá, for example, is associated with Our Lady of the Immaculate Conception; Iansã with Saint Barbara, and so on. See Maggie (I992).

Io Jung (I995) states that catharsis involves the discovery that someone's existence of has meaning within a broader perspective, within a philosophical or religious framework, called a totality by the author. When this awareness is not just contemplated intellectually but lived emotionally, a powerful release of feelings can be produced towards a cure.

\section{BIBLIOGRAPHY}

Coutinho, Tiago. (20I I). Xamanismo da floresta na cidade: um estudo de caso. PhD thesis. PPGAS/Federal University of Rio de Janeiro

Jung, Carl. (1995). Les racines de la conscience. Paris: LGF (Le liure de poche collection).

Kensinger, Kenneth. (I997). Cambio de perspectiva sobre las relaciones de genero. In: Perrin, Michel \& Perruchon, Marie. (eds). Complementaridad de hombre e mujeres, relación de gênero desde a perspectiva ameríndio. Quito: Abaylaya.

Lagrou, Els. (2008). A fluidez da forma: arte alteridade e agência em uma sociedade amazônica (Kaxinawá, AC). Rio de Janeiro: Topbooks.

Losonczy, Anne-Marie \& Mesturini, Silvia. (20 I I). Uncertainty, misunderstanding and agreement communication patterns in ayahuasca ritual interactions. In: Labate, Beatriz C. \& Cavnar, Clancy (eds.). The expansion and reinvention of Amazonian shamanism. Oxford: Oxford University Press,. Maggie, Yvonne. (I992). Medo do feitiço: relações entre magia e poder no Brasil. Rio de Janeiro: Editora Arquivo Nacional. Rehen, Lucas Kastrup Fonseca. (20I I). Música, emoção e entendimento: a experiência de holandeses no ritual do Santo Dai- 
me. PhD thesis. IFCH/Universidade do Estado do Rio de Janeiro.

Rose, Isabel \& Langdon, Jean. (20I0). Diálogos (neo)xamânicos: encontros entre os Guarani e a ayahuasca. Tellus, I0/I8, p. 83-II3.

Viveiros de Castro, Eduardo. (2004). Perspectival anthropology and the method of controlled equivocation. Encontro da Society for the Anthropology of Lowland South America (SALSA), Florida International University, Miami, I7-I8 January. 
Palavras-chave

Xamanismo urbano;

Ayahuasca;

Terapias transculturais;

Espiritualidade nova era;

Ritual terapêutico.

Keywords

Urban shamanism;

Ayahuasca;

Transcultural therapies;

New Age spirituality;

Therapeutic ritual.

\section{O XAMANISMO DA FLORESTA NA CIDADE: O EXEMPLO KAXINAWÁ}

\section{Resumo}

Partindo de situações interativas vividas ao longo de quatro anos de pesquisa de campo, tomo por objeto um ritual terapêutico de consumo de ayahuasca conduzido por dois jovens pajés Kaxinawá na cidade do Rio de Janeiro. Discuto então as compatibilidades equívocas que tornam possíveis a interação de índios e brancos nesse contexto. Apresentando alguns contextos interativos que ultrapassam o eixo espaço-temporal do rito, exploraremos esta sensação de mútua compreensão que acontece graças ao "efeito sinônimo" (synonymy effect). Tal efeito coloca, por exemplo, espíritos e seres mitológicos no mesmo patamar de estados psicológicos e sentimentais, criando um continuum metafórico entre os envolvidos na comunicação. Os dados etnográficos sugerem que os ritos urbanos do Nixi Pae exploram as compatibilidades equívocas entre dois termos que dão origem à comunicação em jogo: Yube e o inconsciente.

\section{FOREST SHAMANISM IN THE CITY: THE KAXINAWÁ EXAMPLE}

\section{Abstract}

Setting out from interactions experienced throughout four years of field work studies, I focus on a therapeutic ritual involving ayahuasca consumption led by two young Kaxinawá shamans. The article undertakes the discussion of the equivocal compatibilities that make possible the interaction between Amerindians and non-Amerindians in this context. Citing a number of interactive contexts beyond the rite's space-time axis, the text explores the sense of mutual understanding that occurs thanks to a 'synonymous effect'. This effect places spirits and mythological beings, for example, on the same psychological and sentimental level, creating a metaphorical continuum between those involved in the communication. Ethnographic data suggests that urban Nixi Pae rites explore the equivocal compatibility between two terms that give rise to this communication context: Yube and the unconscious. 